\title{
Motives and Determinants of China's Foreign Direct Investment in Rwanda
}

\section{HABYARIMANA Jean D'Amour, WU Xiang Feng}

School of Economic and Management, Faculty of Management Engineering, Chongqing Post and Telecommunication University, China

\section{Email address:}

hadjamsu@yahoo.fr (HABYARIMANA Jean D’Amour), wuxf@cqupt.edu.cn (WU Xiang Feng)

\section{To cite this article:}

HABYARIMANA Jean D'Amour, WU Xiang Feng. Motives and Determinants of China's Foreign Direct Investment in Rwanda. International Journal of Economic Behavior and Organization. Vol. 5, No. 2, 2017, pp. 67-72. doi: 10.11648/j.ijebo.20170502.14

Received: December 12, 2016; Accepted: January 19, 2017; Published: April 12, 2017

\begin{abstract}
In the recent past many developing and emerging countries have undertaken a dramatic shift by moving from isolationist, import substitution police to open market policies aimed at increasing foreign direct investment. The main objective of this paper is to investigate if the implementation of China foreign direct investment in Rwanda will have a positive effect in the country. In this paper, we survey some theoretical and empirical literature on the motive and determinant of Chine FDI. Strategic, behavioral and economic consideration appears to the basic motivations for FDIs. In fact the main determinants of FDIs consist of market size variable, labor market conditions, institutional variables, macroeconomic policy variable and global supply of FDIs. This paper states contribution of China FDI's to economic development of Rwanda and the mainly highlights the tangible benefits that FDI's produces both in China and Rwanda. Finally we will propose policy suggestion for Rwanda to attract better and utilize FDI's from China. This paper is no doubt a contribution to the existing literature on FDI and would therefore guide policy reforms on China FDI's in most developing countries especial in Rwanda.
\end{abstract}

Keywords: Motives, Determinants, Foreign Direct Investments. Policy Suggestion

\section{Introduction}

Foreign direct investment can be defined as measure of ownership of foreign direct investment productive assets. Over the past fifteen years, foreign direct investment has become the leading type of capital flow in the global economy, even for developing nations. Its ability to deal with two major obstacles, namely, shortages of financial resources and technology and skills, has made it the Centre of attention for policy makers these countries (ODI, 1997). Several studies find that FDI promotes economic development of the host country by promoting productivity growth (World Bank report, 2002. 2010. 2012).

FDI can be beneficial to both investing firms and host because of this, it is important to consider what qualities attract FDI to particular developing countries. When investors look into injecting capital into the markets of developing nations they take time to assess a country's investment environment including the presence of a legal enforcement procedures, availability of guarantee from government or another multilateral agency (Lamench and Saeed 2008)

The remainder of this paper is to examine the various FDI motivators and determinants China's FDI that have been proposed and tested during the past year. Attempt is also made to review some of the academic literature on the motives and determinant china FDI in Rwanda. It is envisaged that a proper understanding of the major motives and determinants China FDI in Rwanda which is developing country would guide policy choice and facilitate the institution and implementation of appropriate measure to attract FDI in Rwanda.

\section{Motives for FDI}

Strategic Motives, Social Development Motives and Economic Motive for China FDI in Rwanda 
a) Strategic motive

The process of china's reintegration with the global world economy began with the "Open Door" policies in 1979s. Quite soon, in the middle of the 1980s, clear and concrete political motivations for the opening were stated. As Zhan notes, the important aims were to secure a stable supply of resources that cannot be sourced in China, to contribute to foreign exchange earnings and generating export opportunities, and channeling advanced technology and equipment to (Zhan, 1995, p26). The early, selective approach for approval of investment projects has been more and more removed over the years, but the intention of the government to use Chinese FDI has remained valid. As a key stone in 1999, the "go-global" initiative (zhou chu qu) was established, aiming at promoting the international competitiveness of Chinese firms. As part of this initiative foreign exchange related fiscal and administrative obstacle to international investment were gradually removed (Sauvant 2006, p12).

This section will be analyses motivation and strategies of Chinese MNEs. We will examine the main drive of Chinese and Rwanda MNEs separately for the sake of clarity, but it is worth noting that in most cases motivations might be mixed, complementary or evolutionary, in fact, and as stated before, the application of tradition approaches to explain motivation for FDI (Dunning 1999. p30) seems to be the most appropriate way to address the phenomenon, since Chinese MNE are engaging an international, capitalist business environment, where, most strategies are following intention such as market seeking or efficiency seeking and strategic asset- seeking.

The studies of multinational firms indicate that their motivations for making foreign direct investment are based on strategic consideration of five main types according to [Hogue, 1967, nehert and Hogue 1968, UNCTAD 1998] 1. Market seeker 2. Raw material seekers 3. Production efficiency seekers; 4. Knowledge seekers 5. Political safety seekers.

Market seeking FDI: Generally market seeking investors will be attract to a country with a large local market and fast growing market: Resource seeking investors will be look for a country with abundant natural resource while efficiency seeking investors will weigh more of geographical proximity to the Home country to minimize the transportation cost [Taylor, 2002, zhang, 2003, Kinoshita and Campos 2002. p3].

As suggest by the theory, FDI in nearby regions is the most common location for market seeking affiates in the case of most developing countries FDI. However, in the case of Chinese FDI in many manufacturing industries as well India in IT services, the Republic of Korea in advanced manufactures and the Russian Federation in natural resources, proximity is less relevant for some important FDI attracted by developed country markets [UNCTAD WIR, 2006, p. 158]. In case of China FDI, most investment do follow successful, established export stream, and destination might be neighboring do follow successfully. As Zhan point, market seeking motivations are the logical consequence of China's export oriented policy over the last years. The firms follow their export channels to expand market shares and avoid trade barriers [zhan, 1995, p 87]

Efficiency Seekers. Produce in countries where one or more of the factor of production are underpriced relative to their productivity. Foreign investment is said to efficiency seeking when the firm can gain from the common governance in the presence of economy of scale and scope [compos and yuko, 2006].

Most scholars agree that given the low production cost in china, efficiency- seeking motivations do not play the prime role for Chinese MNE going global [Buckley et.al, 2007, p.501]. However, a few examples may point to growing role of efficiency motivated Chinese FDI in the year to come. For lobour intensive production such as textiles, the situation has become more dynamic over the last months, since wages has considerable increased in the coastal areas of China.

Knowledge seekers. Operate in foreign country to gain access to technology or managerial expertise. An econometric study of Norwegian manufacturing firms over the period 1990 to 1996 by Grunfeld [indicates that foreign investors predominantly try to exploit their technological advantages in the Norwegian market]. The results also show that the presence of foreign ownership is more volatile in highly research and development intensive firms. FDI is the main conduit through which technology transfer takers place [Ajayi, 2006].

Strategy assets seekers. Generally, strategic asset -seeking is often aiming at the acquisition of information and knowledge on how to operate internationally. However, with growing experience of Chinese firms in this, their goal has rather turned to concrete intangible assets, such as advanced proprietary technology and immobile strategic assets, both through Greenfield investments and acquisitions. The acquisition of foreign technologies and brands is often regarded as a short- cut to establish a company as an internationally known, quality producer with a portfolio of latest technologies and services, and an efficient distribution channel. Acquisition will function as a fast route to such benefits and in addition, will also deny them to competitors [child \&Rodriguez 2005, p. 392]

Politic safety seekers. Acquire or establish new operation in countries that are considered unlikely to expropriate or interfere with private sector firms. It should be noted, however, that strategic rather than financial considerations 
seem to be very important motivations for direct foreign investment. Therefore, although discounted cash flow analysis is still used appropriately to analysis is still used appropriately to analyze specific projects; it is not usually the deciding for factor in choosing the original countries in which a multinational firm will invest [Luo \&Tung 2007. p. 105]

Conclusion in the case of emergence country MNEs, it has been argued that these firms engage in FDI in developed and emerging countries for different motives. They largely seek strategic assets when entering developed countries but pursue market opportunities when operating in emerging countries [Luo \& Tung, 2007.p. 46]

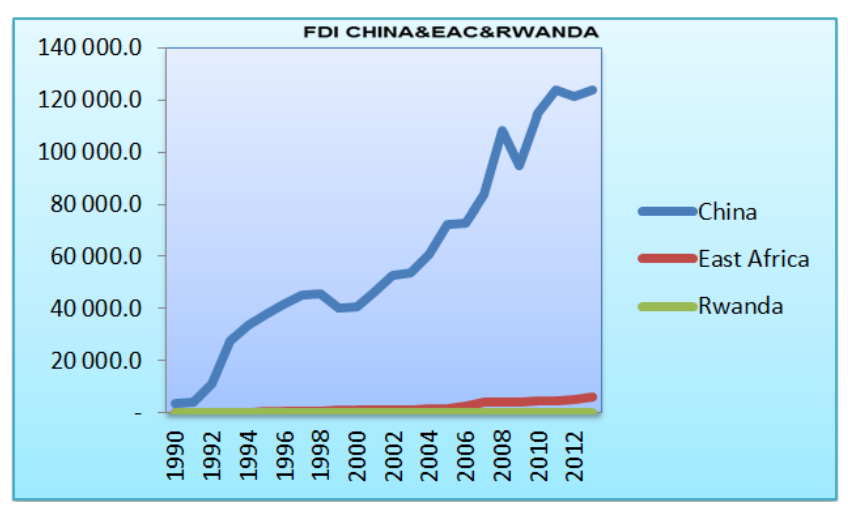

Source: UNCTAD, FDI/TNC database (www.unctad.org/fdistatistics).

Figure 1. China\& EAC and Rwanda's FDI inflow since 1990-2013.

b) Social development Motives

A study of behavioural aspect of the FDIs decision process found two sets of motive. One set arose from a stimulus from the external environment and the other from within an organization on the basis of personal biases, needs and commitments of individuals and groups [Aharoni's.1966]. An outside proposal provided it comes from a source that cannot be easily ignored. The most frequent source of such proposal are foreign government, the distributors of the company's products, and its clients, Fear of losing a market, The bandwagon effect: Very successful activities abroad of a competing firm in the some line of business, or general belief that investment in some area is a must strong competition from abroad in the market [Mustafa \& Cansu YÖRÜKOĞLU. 2005. p. 5]

In addition to the above four motives, Ahoroni \& Mustafa found some auxiliary motives for foreign direct investment: 1. Creation of a market for components and other products; 2. Utilization of old components and other products; utilization of old machinery; capitalization of know-how spreading of research and development and other fixed cost; and 4 . Indirect return to a lost market through investment in a country that has commercial agreement with these host territories.

The behavioural approach to the foreign investment decision is usually specific decision on a specific opportunity evaluated sequentially in response to a specific motivating force. The sequence and intensity of investigation including the strength of the motivating force, thus becomes the major determinant of FDI decision.

c) Economic motive

Product and fact market imperfections product and market imperfection open the door to direct foreign investment. Market imperfection may occur naturally, but they are usually attributed to police of firms and governments.

The most important competitive advantage enjoyed by multinational firms are:

(1). Economies of scale arising from their large size

(2). Managerial and marketing expertise

(3). Superior technology owing to their heavy emphasis on research

(3) Financial strength

(4). Differentiated products

Product cycle theory: Raymond and his colleagues were proposing another version of direct foreign investment theory based on product differentiation with a time lag. [VERNON '2010] product cycle theory requires imperfections in both the market for products and market for factors of productions. It suggests that direct foreign investment is a natural stage in the life cycle of new products from its inception to its maturity and eventual decline. New products are first introduced in the home market. After a short time lag the product is expected. As the new product reaches maturity, competition from nearly similar products narrow profit margins and threatens both export and the home markets. At this stage foreign manufacturing locations are sought where market imperfections in the cost of factors of production create a chance for lower unit production cost. Thus the foreign investment is essentially a defensive investment designed to preserve profit marginal in both export and home markets. However apart from the classical

The classical trade theory, more recent theories explain why firms should undertake foreign direct investment, licensing, and management contracts instead of continuing to rely on exporting and importing. Some of these theories are discussed below:

a. Comparative advantage: the theory of comparative advantage and its corollary, the theory of factor production provide a basis for explaining and justifying international trade in a model world assumed to enjoy free trade perfect completion, no uncertainty, costless information, and no government interference. Nevertheless although the world is long a long way from the classical trade models the principle of comparative advantage.

b. International capital movement: classical theory postulated the international capital movement were 
motivated either by interest differentials for securities of risk or by trade imbalances. In the classical model interest differentials signaled the existence of different balance between investment opportunity and resources available for investment [Grubel 1977. p47]

c. Follow the leader: Frederic Knickerbocket developed a theory of defensive direct foreign investment. When one competitor undertaker a FDI other competitor follow very quickly with defensive FDI into that market. Direct investments are less profitable and riskier than themselves.

d. Credulity: Defensive investment also occur when credibility with existing customer base become important.

e. Product and factor market imperfection. The modern theory of foreign direct investment can be traced to Stephen Hymen's 1976. Hymer was the first person to identify imperfections in national and international markets for products and factors of production as precondition for most direct foreign investment.

According to the Hymen: Theory product and factor market imperfection open the door to direct foreign investment. Imperfections may occur naturally, but they are usually attributed to policies of firm and government the most important competitive advantages enjoyed by multinational firms are: (1) Economic of scale arising from their size empirical studies lend some support to the hypothesis that multinationals must be large to success [Horst, 1972]

(2) Managerial and marketing expertise;

(3). Superior technology owing to their heavy emphasis on research empirical studies has supported the importance of technology as a characteristic of MNEs [Veron 1966. p125]

However synthesizing all the theories of foreign direct investment based on market imperfections is difficult Nearly all the empirical test show FDI originates in firms that are large, research intensive and subject to oligopolistic competition from domestic and foreign firms.

\section{Rationale for China Investing in Rwanda}

Rwanda is country offering significant opportunities for foreign investors with its geographically perfect position to function as a gateway between EAC Middle East and Central Africa. The opportunities exist not only in the Dynamic domestic market, but also throughout the region. Hospitality and tolerance being the traditional cornerstones of the Rwanda way of life the country is open to foreign investors with much attraction to offer.

a. Larger and growing domestic market

b. Mature and dynamic private sector

c. Leading role in the region d. Liberal and secure investment e environment

e. Supply of high quality and cost effective labor force

f. Customs union with EAC countries

g. Developed infrastructure

h. Institutionalized economy

i. Competitive tax system

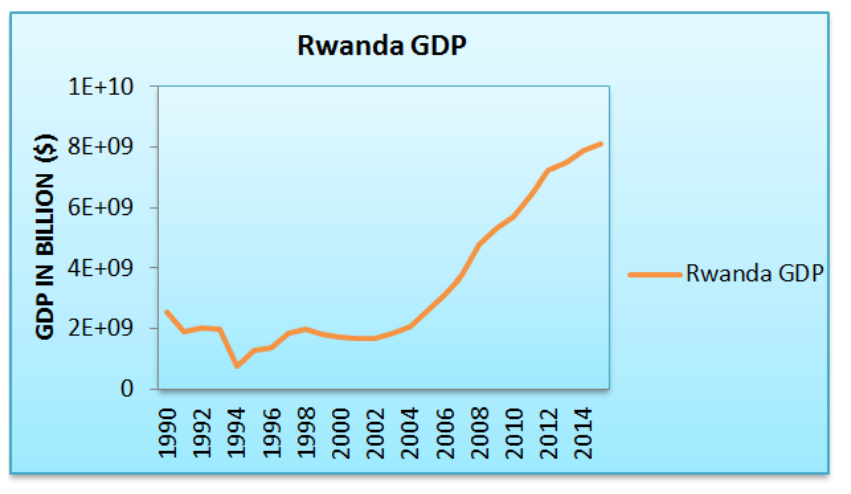

Source. World investment report (www.worldinvestment.org/gdpstatistics)

Figure 2. Rwanda FDI's since 1990-2015.

\section{Determinants of China FDI in Rwanda}

There are so many factors that determine foreign direct investment into geographical location. The list of these determinants may be very long, but not all determinants are equally important to very location at all time. Dunning [1982] argues that three conditions must be satisfied simultaneously for FDI to occur. The firm must have both ownership advantage and an internalization advantage, while the foreign market must offer a location advantage. The ownership advantage steams from the firm's ownership of intangible assets, such as technology, patents and skill management.

The location advantage arises from the assets that foreign market supply such as abundant natural resources, large market size cheap factor of production and friendly business environment.

UNCTAD'S [1998] world investment Report presents some host country determinants of FDI. These include: Economic, political and social stability; Rules regulating entry and operation (of FDI's); standard of treatment of foreign affiliates; policies on functioning and structure of the markets; international agreement on FDI; Privatization policy; trade policy

Ajayi [2006] contends that FDI flows are influenced by both pull and push factors. The push factors are mainly growth and interest rates in the industrialized countries while the pull factors consist mainly of host country characteristics and policies. Higher economic growth reflects improvement in productivity and development, lower economic political risk will result in a more attractive and stable climate for foreign investors. The infrastructure in the host country will influence the extra 
expenditure of the multinational. The basic infrastructure constructions are necessary for attracting the investment.

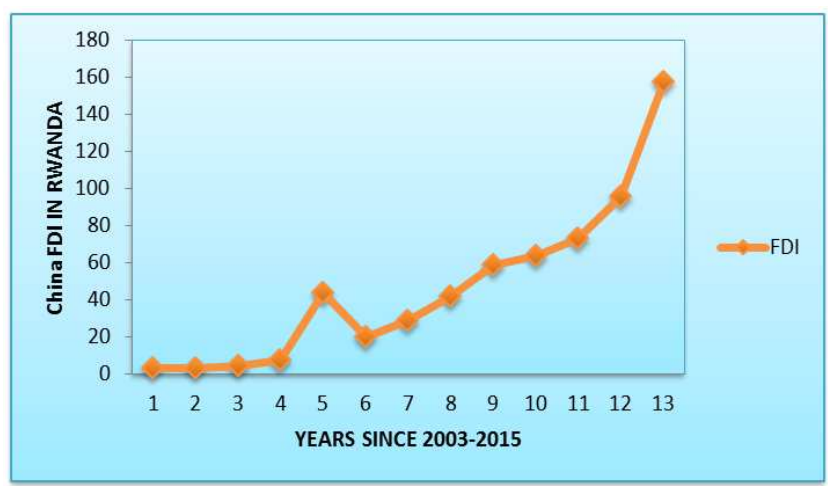

Figure 3. China FDI's to Rwanda (Source: Ministry of commerce of the People's Republic of China and National Bureau of statistics of China. Statistics bulletin 2015).

In fact parties for the determinants I mention above they are other determinants of FDI include language and business the strength host county currency, economic and structural reforms privatization, liberalization, existing technologies, non-discriminatory treatment of investors, consistency and predictability in government policy.

\section{Empirical Evidence on Determinants of China's FDI in Rwanda}

Theoretically, FDI has been classified into two types: market oriented and exported FDI. In terms of market oriented FDI, the most important factor to attract FDI in the size and growth of the host country. The export oriented FDI mainly looks for cost competitiveness [OECD, 2000] in this section is to examine some empirical study of motives and determinants of China FDI in Rwanda.

Size of the market: The size of the domestic market and growth prospects of recipient are highly taken into consideration when foreign investors relocate production in the country. Rwanda is hub for rapidly integrating East Africa located centrally bordering 4 countries, in East Africa, part of EAC common market and custom union with market potential of over 125 million people.

Political risk: political stability and security of life and property in Rwanda have also been mention as factor attraction FDI.

Infrastructure: Infrastructure consists roads, port, supply of energy water sanitation and telecommunication systems and institution development.

Openness: A range of surveys suggest a widespread perception that Rwanda has Open economies encourage more foreign investment.
Incentive and operating conditions: ODI[1997] report that most empirical evidence support the nation that specific incentives such as lower taxes have no major impact on FDI. on the other hands, Rwanda adapt the police for removing restrictions and providing good business operating conditions are generally believed to have a positive effect. Further incentives such as the granting of equal treatment to foreign investors in relation to local counterparts and the opening up of new market have been reported as important factors in encouraging FDI.

\section{Conclusion}

In this paper motive and determinants china's FDI in Rwanda I noted that FDI always motivated by certain basic factor and that there are so many factors that determine FDI into the geographical location. In fact main motivation of Rwanda FDI is motives derived from their operation in an international capitalist market economy. Rwanda has mostly market seeking, resource seeking strategic asset seeking and efficiency seeking motivations. On the other hand the key FDIs determinants consist of market size variable, labor market condition institutional variable policy variable and the global supply of FDIs. China's FDI to Rwanda has in recent increased exponentially. In 2005 Chinese in Rwanda reached 4.6 million US Dollars and bye the of 2014 this had increased to 108.5 million US Dollars. This has caused a great debate of the motives behind the increased Chinese presence in Rwanda.

According to motives found in the analysis Chinese FDI in Rwanda is attracted with location geography in EAC, and large market and natural resources in the EAC. There is no evidence that Chinese FDI is more attracted to natural resources in Rwanda, the results indicate that Rwanda good institution in interaction with natural resource are determinant of Chinese FDI in Rwanda.

I have also looked whether Chinese investment in Rwanda are different than Chinese elsewhere. The result from this suggestions that GDP or market size, and trade openness, in addition to natural has significant association with globally and thus, the Chinese FDI globally is market-seeking and resource-seeking.

The determinants of Chinese FDI in Rwanda revealed in this paper do not appear distinctive per se. However the fact that FDI is only one component, whereas trade and aid is the other two in the Chinese on Rwanda, I suggests that we need to look beyond different in investment flows only to assess the full impact of china's impact in Rwanda development, for stance a lot of the official development aid may in some aspect to be similar to FDI. 


\section{References}

[1] Akpansunga \& Aniekan Okon, Motives and Determinants of Foreign Direct Investment: A survey of literature [J] European Journal of Humanities and social sciences, 2013(1) p: 12-15

[2] Ajiyi, s. 1 (2006). The Determinants of foreign direct investment in Africa: a survey of the impact and potential, African economic Research consortium, Nairobi Kenya level [J] journal of Africa economic research, 2006. p:209-215

[3] Bevan, A. A \& Estrin, S. (2004), the determinants of FDI into European transition economies [J] journal of comparative economics, 32(4):775-787.

[4] Child, J. and S. B. Rodrigues (2005). "The internationalization of Chinese firms: a case for theoretical extension?" Management and organization review (3): 381-410.

[5] Compos and YUKO, (2006) Sectoral composition of foreign direct investment and external vulnerability [M] working paper International monetary fund 2006 (1) 1-48.

[6] Dunning, J. (1998) location and multinational enterprise: A neglected factor? Journal of international business studies Vol. 29. No. 1, 45-66.

[7] Host; T. (1972) "Firm and industry determinants of the decision to invest abroad: An Empirical study", Review of economics and statistics, August.

[8] Hymer, S. (1976), the international operation of national firms: A study of foreign direct investment flow [M] mass. Cambridge: MIP Press $\left(15^{\text {th }}\right.$ may 1976) p.200-222.

[9] Jere Vilkman Motives and location factors of China foreign direct investment in Finland and Sweden [D] Turun yliopisto University of Turku 2011. P: 17-35.

[10] NBS/MOFCOM. Statistical Bulletin of China's outward Foreign Direct investment in 2015[M]. Beijing China statistic press, 2015.

[11] ODI (2010), Foreign Direct Investment flows to low -Income Countries: Review of evidence Overseas Development Institute. September. www.odi.org.uk/publication s

[12] ODI (2010), Foreign Direct Investment flows to low -Income Countries: Review of evidence Overseas Development Institute. September. www.odi.org.uk/publication s

[13] Phileppe Gugle \& Bertram Boie. The emergence of Chinese FDI: Determinants strategies of Chinese MMEs. Copenhagen business school, $10^{\text {th }}$ October 2008 paper presented at the conference. P: 9-20.

[14] Prabhakar, AC., (2010) an investigation of the global economic and financial crisis African journal of marketing management 2[3] pp. 044-068.

[15] UNCTAD FDI $\backslash T N C$ database (www.unctad.org/statistics)accessed on the $5^{\text {th }}$ September 2016.

[16] Vincent Byusa (2010), Chinese external to assistance to Rwanda [J] NUR-Rwanda journal of social sciences, 2010(19) 75-80.

[17] World investment report (www.worldinvestmentreport.org )accessed on the $20^{\text {th }}$ august 2016.

[18] Tori Carmel High: (2009) To Rwanda and Back: A study examining the feasibility of successful foreign direct investment in Rwanda, [D] University of Arkansas, 2009.

[19] Zhan, X (1995) .Foreign investment policy, contribution and performance, in foreign direct investment and economic growth in China [M] conference paper 24-25, 2006[ 4] pp.510 .

[20] Sauvant, K. P (2006). New sources of the FDI: Bric's .Outward FDI from brazil, Russia, India and China. [J] journal of World Investment \&Trade 6 (October), 639-709. 